\title{
The Capitalized society subjugates the weak: Perspectives; Death of a Salesman
}

\author{
Azmi Azam \\ Anglia Ruskin University, Cambridge, England.
}

\begin{abstract}
Death of a Salesman is centered on one man trying to reach the American dream and taking his family along for the ride. Loman's life from beginning to end is a troubling story based on trying to become successful, or at least happy. Throughout their lives, the family encounters many problems and the end result is a tragic death caused by stupidity and the need to succeed. During his life, Willy Loman caused his wife great pain by living a life not realizing what he could and couldn't do. Linda lived sad and pathetic days supporting Willy's unreachable goals. Being brought up in this world caused his children to lose their identity and put their futures in jeopardy. At the end, we certainly realize what are the forces that led Loman towards his death. His society enforces him to embrace death as the possible solution, and society helps him to act like a brute. His family is brutally treated to its doom and uncertainty though he sacrifices himself in the alter of a capitalist society that brutally holds the oppressive guillotine of manipulation, exploitation and profit-making attitude.
\end{abstract}

Keywords: communism; capitalism; exploitation; dream; brutalization; socialism.

\section{Council for Innovative Research}

Peer Review Research Publishing System

Journal: Journal of Advances in Linguistics

Vol 2, No. 2

editor@cirworld.com

www.cirworld.com, member.cirworld.com 


\section{Introduction}

Willy Loman is the protagonist of the celebrated play that eyes the exploitative brutality of the society, and Loman proves an unsuccessful who fails to make a compromise with the society he lives. Death of a Salesman is a play that depicts how a capitalist society can manipulate its subjects. Consumerism, Mercantilism, Illusion, Marxism, Lacanian praxis, Hobbes' thoughts and Existentialism can be our guiding stars in the way to understand how a capitalist society can brutalize the unsuccessful. Willy Loman stands as the paragon example of an American dream that dooms utterly due to the adverse forces that ruins his life, existence and dream.

At first, we need to clarify what a capitalist society is, who a capitalist is , how capitalism captures the things around it, and what the means are-these questions are pragmatic in the context of Death of a Salesman. Capitalism is a social system based on the principle of individual right; (The term capitalism is used here in the broader philosophical political sense, and not in the narrower economic sense, i.e. a free-market.) and a capitalist is an advocate of laissez-faire, i.e., novelist Ayn Rand is a capitalist; i.e., though economically Engels came from a wealthy background, politically he is recognized as a socialist/communist because of his ideas. Thus, the society that upholds the ideas of capitalist dictums are considered to be capitalist societies, and a capitalist society always try to make its subjects subjugated under its hegemonic oppression through some brutal means.

In first place, we can think of existentialism as an answer to what Loman suffers. How much freedom can one get to defy the process of brutalization? Considering the Existentialism, does freedom permits Loman to ignore the established rules of life? We are condemned to live a life, we have only two options-either or live the life or to decease it. Like the rules of god, a proletariat is condemned to live a life in a capitalist and capitalized society. Either Loman has to embrace the rule of Howard-like people or he has to renounce it by embracing the process of alienation; but until he gets the assistance of political, economic and social powers, he cannot overrule the bourgeoisie supremacy, thus death is the destiny he suffers. In Albert Camus' The Outsider, we can also trace the essence of alienation as a protest against the brutalization. Meursault is forced to embrace death as a solution of his denial-denial of society, of state, of ethics and of hegemonyand at the end, he realizes the loopholes of hegemonic oppression that hegemony allows only two options-either to embrace the solution given by or to embrace alienation/death. Loman also suffers the same process when he voices against brutalization. Being irked by the painstaking progress of brutalization brutality of the society, he embraces death. Before that, he has tried all his efforts to maintain his dreams alive-he has mortgaged his property to put the insurance scheme valid, he has begged privileges from Howard, he has tried to establish his sons; but all the things has gone vain due to the inconsistency and uncooperative mood of the society. Society only knows how to make things profitable, and an old man like Loman is hardly a concern for a society that is lead with the principles of 'survival of the fittest'. As if human being is in this earth not for life's sake but for survival's sake, and the survival comes not in humanized way but in a brutal way, in the apes get transformed into human beings as believed by Darwin and his theory.

Thus, capitalist society is society that is obsessed with self-obsessed individuals. Self-obsession leads to narcissism. Loman lives in a society that is narcissistic in its character. Every individual is busy with his own routine, and hardly a person gets the chance to share the things with others. Howard is a paragon example of such a thing because he enjoys the voices recorded in the tape recorder he has purchased, and it symbolizes the narcissistic feeling that 'l' is the most important thing in every concern. Loman is a victim of such a brutal society because his dreams are not only of his own, but also of others-his home, his wife, and his sons. This brutish brutality is also manifested in Allen Ginsberg's "Howl":

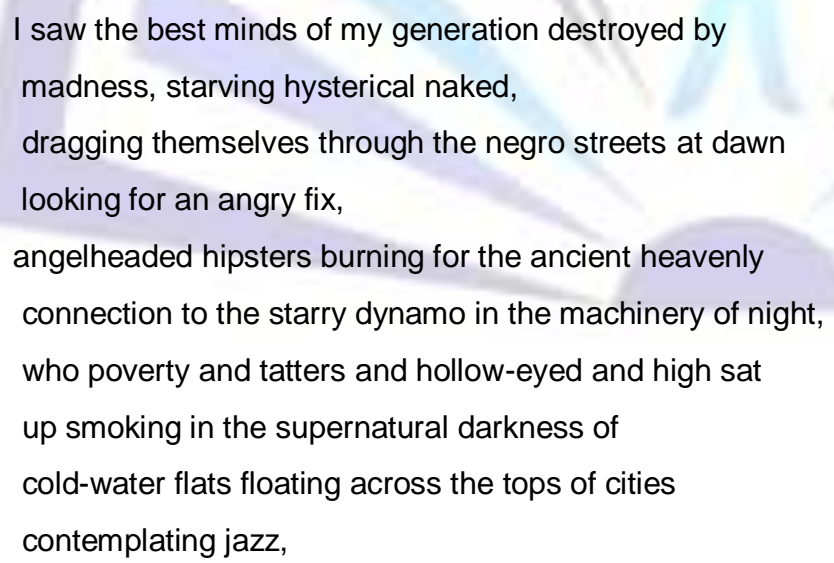

Thus, Loman lives in a society that brutalizes the unsuccessful.

In the context of Marxism and Das Capital, we can also observe how society force a man into brutality. According to Marx, the means of production are a combination of the means of labor and the subject of labor used by workers to make products. The means of labor include machines, tools, equipment, infrastructure, and "all those things with the aid of which man acts upon the subject of labor, and transforms it". The subject of labor includes raw materials and materials directly taken from nature. Means of production by themselves produce nothing -- labor power is needed for production to take place. A capitalist society tries to brutalize the mass people because it needs labour in cheap price, so Loman-like people are needed in such a society to make the luxury and comfort enjoyed by the Howard-like oppressors. And, at the end, the 
contribution of Lomans is forgotten because they are no more needed when they are at the end of their service, and of their age.

In capitalism, the motive for producing goods and services is to sell them for a profit, not to satisfy people's needs. The products of capitalist production have to find a buyer, of course, but this is only incidental to the main aim of making a profit, of ending up with more money than was originally invested. This is not a theory that we have thought up but a fact you can easily confirm for yourself by reading the financial press. Production is started not by what consumers are prepared to pay for to satisfy their needs but by what the capitalists calculate can be sold at a profit. Those goods may satisfy human needs but those needs will not be met if people do not have sufficient money. The profit motive is not just the result of greed on behalf of individual capitalists. They do not have a choice about it. The need to make a profit is imposed on capitalists as a condition for not losing their investments and their position as capitalists. Competition with other capitalists forces them to reinvest as much of their profits as they can afford to keep their means and methods of production up to date. Thus, when the question of Mercantilism or Consumerism comes, we ca $\mathrm{n}$ have a comparative look with Allen Ginsberg's "A Supermarket in California" where he voices against the undoing of a consumerist society that only knows how to make profits, and how to make people brutalized:

Where are we going, Walt Whitman? The doors close in

an hour. Which way does your beard point tonight?

(I touch your book and dream of our odyssey in the supermarket and feel absurd.)

Will we walk all night through solitary streets? The

trees add shade to shade, lights out in the houses, we'll both be

Ionely.

Will we stroll dreaming of the lost America of love

past blue automobiles in driveways, home to our silent cottage?

Here Ginsberg asks Whitman the basic questions regarding the goal of a American society that leads people towards a capitalist and brutal end. As if we can picture the image of Howard or Ben, who is brutalized to live a life like an animal. Howard's tape recorder reminds us the presence of a society that is led by the gross forces of profit and benefit. And Willy righteously says that:

Biff Loman is lost. In the greatest country in the world a young man with such-personal attractiveness, gets lost. And such a hard worker. There's one thing about Biff-he's not lazy.

Here we feel the pains of a father who fails to fulfill the dreams of his own, and also of his sons due to the reigns of consumerism, mercantilism and industrialization .

Marx and Engels also use the term "base-structure" to explain the idea that the totality of relations among people with regard to "the social production of their existence" forms the economic basis, on which arises a superstructure of political and legal institutions. To the base corresponds the social consciousness which includes religious, philosophical, and other main ideas. The base conditions both, the superstructure and the social consciousness. A conflict between the development of material productive forces and the relations of production causes social revolutions, and the resulting change in the economic basis will sooner or later lead to the transformation of the superstructure. For Marx, though, this relationship is not a one way process - it is reflexive; the base determines the superstructure in the first instance and remains the foundation of a form of social organization which then can act again upon both parts of the base-structure metaphor. The relationship between superstructure and base is considered to be a dialectical one, not a distinction between actual entities "in the world". Thus in the context of American society, we can trace the things lying in base and super-structure. Loman and Howard live in a society that is lead by the beliefs of an industrialist, of a businessman, of a bourgeoisie. Howard, Ben, Charley are the force behind the society that control everything. In base-structure, the ideas, beliefs and ethics are the leading forces that shape a society like America, and in super-structure, economy is the leading force that leads the society through. Loman is an unsuccessful man, he is victim of brutality-the reason is the forces that lead the society trough are none of his concern. Loman is a symbol of 'outsider' who have no choice but to choose death or slavery. Even Howard and Ben are also enslaved in the void of their own shackles - the nothingness of life. When Loman is forced to embrace death, he satirizes the forces of society that maintain a dialectical relation between economy and legal institutions. Loman is denied with the righteous right of privileges claimed by him form Howard, and Howard proves himself a mechanized brute who posses no choice but to treat Loman in a brute way. Here, the sense of profit makes Howard brute, and he thinks Loman unprofitable to his business; but he fails to understand that once he will also be thrown away in the he throws away Loman because he is nothing but a mere tool of oppression forced by the 'basestructure' of the society.

Death of a Salesman is a criticism of a capitalist society like Loman's because it symbolizes the failures of the oppressors. Bourgeoisie possesses a sense of class-consciousness that maximizes the relations between every person. Like the diabolical relation of Lucky and Pozzo in Waiting for Godot, a relation that symbolizes the enslavement of personalities, Loman and Howard are symbol of characters that utterly fail to reach a solution between them regarding the oppression and justice. Pozzo is tied with Lucky through the shackles and whip he holds, and Howard is fated to get tied with the 
shakes created by his own choices. Marx believed that the identity of a social class is derived from its relationship to the means of production (as opposed to the notion that class is determined by wealth alone, i.e., lower class, middle class, upper class). Marx describes several social classes in capitalist societies, including primarily: the proletariat: "those individuals who sell their labour power, (and therefore add value to the products), and who, in the capitalist mode of production, do not own the means of production", the bourgeoisie: those who "own the means of production" and buy labour power from the proletariat, who are recompensed by a salary, thus exploiting the proletariat, the petit bourgeoisie are those who employ labour, but may also work themselves. These may be small proprietors, land-holding peasants, or trade workers. Thus brutalization is the fate Howard suffers as a bourgeoisie or a petit bourgeoisie, and American society has no other choice but to get ahead with the process of brutality and brutalization.

Question of hegemony and power is also a central issue that controls the whole narrative. The ideas of human society are very much capitalist is characteristics. The over-imposed duality makes our beliefs that the diabolical relation is the destiny we suffer. Proletariat and Bourgeoisie are two different classes of people that can never have a compromise. Like the Sun and the Moon, like the Proton and Electron, like West and East, like Rational and Irrational, like a Ruler and Ruled, like a cipher and unending straight line, this relationship is perpetual and universal. As society has transformed itself from a 'Primitive' to a "Modern' one, capitalist society believes that the present existence is the destiny. In doing so, society tries to brutalize the human relations. In two ways, first-it creates some brute persons who spread the theory and practise of brutality, second-it makes some victims who are brutalized to suffer the process. Ideology and Ideological State Apparatus (an idea closely related to Antonio Gramsci's concept of hegemony) are the two prime concerns of Louis Althusser who suggests our society is also led by these two forces. Ideology is a belief ascertained by the hegemonic power, and ISA (Ideological State Apparatus) is an established force of the state that enforces society to embrace its ideology by force. Whereas hegemony is ultimately determined entirely by political forces, ideology draws on Freud's and Lacan's concepts of the unconscious and mirror-phase respectively, and describes the structures and systems that allow us to meaningfully have a concept of the self. These structures, for Althusser, are both agents of repression and inevitable - it is impossible to escape ideology; to not be subjected to it. The distinction between ideology and science or philosophy is not assured once and for all by the epistemological break: this "break" is not a chronologically-determined event, but a process. Instead of an assured victory, there is a continuous struggle against ideology: "Ideology has no history." In Death of a Salesman, we also see the similar scenario. State is the lead force that controls the society. It is a part of Superstructure, and ideology victimizes the people. American society is capitalist is characteristics, and the state preserves the intention to capitalize everything within it. In Althusser's view, our values, desires and preferences are inculcated in us by ideological practice, the sphere which has the defining property of constituting individuals as subjects through the process of interpellation. Ideological practice consists of an assortment of institutions called Ideological State Apparatuses (ISAs), which include the family, the media, religious organizations and, most importantly, the education system, as well as the received ideas they propagate ${ }^{[2]}$. There is, however, no one ISA that produces in us the belief that we are self-conscious agents. Instead, we learn this belief in the course of learning what it is to be a daughter, a schoolchild, black, a steelworker, a councilor, and so forth. In Loman's case, state acts as a assistant force towards his doom. Howard is empowered with the power of legal system, of laws, of legitimacy of production system, of profit and manipulation. Thus Howard is second god to Loman who can decide his fate-his life and his death; and when the time comes, Howard, being inspired by the ISA, brushes Loman aside because he is no more a effective tool for the goals set by the society and the state. Profit and profit only is the goal of Howard's society, so he diminishes the forces that act against the ideology of the state-capitalism.

Marx refers to the exploitation of an entire segment or class of society by another. He sees it as being an inherent feature and key element of capitalism and free markets. The profit gained by the capitalist is the difference between the value of the product made by the worker and the actual wage that the worker receives; in other words, capitalism functions on the basis of paying workers less than the full value of their labor, in order to enable the capitalist class to turn a profit. This profit is not however moderated in terms of risk vs. return. And, Marx also refers to the alienation of people from aspects of their "human nature" ("Gattungswesen", usually translated as 'species-essence' or 'species-being'). He believes that alienation is a systematic result of capitalism. Under capitalism, the fruits of production belong to the employers, who expropriate the surplus created by others and in so doing generate alienated labour. Alienation describes objective features of a person's situation in capitalism - it isn't necessary for them to believe or feel that they are alienated. Loman suffers both-exploitation and alienation as a destiny. Loman and his family suffer the process of brutalization being ousted by the forces of exploitative society. Linda, Biff, Happy and Loman-these characters are manipulated, exploited and alienated at the end. As Willy says in Act 2:

I put thirty-four years into this firm, Howard, and now I can't pay my insurance! You can't eat the orange and throw the peel away-a man is not a piece of fruit! (Miller, 59)

Here, the intonation remains that how a character could be manipulated only for the sake of profit, how a righteous claim can be overturned only for the sake of financial benefits. Thus, it is a gleam picture of society that is brutalized; a society that is brutal in its nature and that teaches its people how to be brutal. Moreover, it also suggests us how individuality leads us towards isolation, as we also observe it in TS Eliot's "Love Song of J.A. Alfred Prufrock". Prufrock, like Loman, lives in a society that instigates a man to live a segregated, alienated, isolated life through the progress of brutalization.

Society formation is also a primary force against the individuals who are brutalized severely. In the way to formation of society from 'Primitive Society' to 'Modern society', so many changes have come. These societal changes ultimately help the forces that enforce the individuals like Loman to get brutalized. The Marxist theory of historical materialism understands society as fundamentally determined by the material conditions at any given time - this means the relationships which people enter into with one another in order to fulfill their basic needs, for instance to feed and clothe 
themselves and their families. In general Marx and Engels identified five successive stages of the development of these material conditions in Western Europe. Primitive Communism (tribal), Slave Society, (Aristocracy), Feudalism ( Merchants), Capitalism (capitalists) and Socialism / Communism (autocracy of workers) -these are the societies termed by Marx who believes that capitalist society is the last step before socialism. Like Nora (feudal society) in $A$ Doll's House Hester Prynne (aristocratic, Puritan society) in A Scarlet Letter, Loman is also fated to live the rule of capitalist society that dominates every concern of his life, and decides his choices that brutalizes him.

Death of a Salesman can also be analyzed under the thoughts of Hobbes. We can judge the cause behind Loman's failure, and the possible explanations of his failure. In Leviathan, Hobbes set out his doctrine of the foundation of societies and legitimate governments. When threatened with death, man in his natural state cannot help but defend himself in any way possible. Self-defense against violent death is Hobbes' highest human necessity, and rights are borne of necessity. Thus Loman serves his necessity that he need to commit suicide to make his sons established, have a good, secured future of his family and to get rid of poverty he suffers. As if, Loman is in the state of nature, then, each of us has a right, or license, to everything in the world. Due to the scarcity of things in the world, there is a constant, and rights-based, "war of all against all" (bellum omnium contra omnes). Life in the state of nature is "solitary, poor, nasty, brutish, and short". According to Hobbes, society is a population beneath an authority, to whom all individuals in that society covenant just enough of their natural right for the authority to be able to ensure internal peace and a common defense. This sovereign, whether monarchy, aristocracy or democracy (though Hobbes prefers monarchy), should be a Leviathan, an absolute authority. Like manner, Loman's society is a symbol of complete authority over its subjects, who bent down under the dictums of capitalist dogmas. Law, for Hobbes, is the enforcement of contracts. The political theory of Leviathan varies little from that set out in two earlier works, The Elements of Law and De Cive (On The Citizen).Hobbes' leviathan state is still authoritative in matters of aggression, one man waging war on another, or any matters pertaining to the cohesiveness of the state. It should say nothing about what any man does otherwise; so long as one man does no harm to any other, the sovereign should keep its hands off him (however, since there is no power above the sovereign, there is nothing to prevent the sovereign breaking this rule). In actuality, however, the extent to which this sovereign may exercise this authority is conditioned by the sovereign's obligations to natural law. Although the sovereign has no legislative obligations, it is more beneficial for him to abide by those laws which prescribe peace for security (the laws of nature). Thus this conditions the authority of the sovereign with a prudential morality, or, more accurately, a moral obligation. A sovereign also maintains equality within the state, since the common people would be "washed out" in the glare of their sovereign; Hobbes compares this "washing out" of the common people in their sovereign's presence to the fading of the stars in the presence of the sun. In essence, Hobbes' political doctrine is "do no harm." His negative version of the Golden Rule, in chapter xv, 35, reads: "Do not that to another, which thou wouldst not have done to thyself." This is contrasted with the Christian golden rule, which encourages actively doing for others: to Hobbes, that is a recipe for social chaos. In Hobbes' context, Death of a Salesman is a symbol of authority a society enjoys upon its pupils to control and manipulate.

Willy Loman is also a symbol of dream, an American man who dares dream the things he desire most, a home, a better living, establishment of his sons, his pension, his insurance. He lives in a nexus of dreams, and when the illusion ends, he embraces death. Like a somnambulist, he walks the road of life. In the end, he appears to be a picture of failure. He fails to maximize his dreams. He cannot understand his sons. He cannot satisfy his customers anymore. He cannot materialize his dreams. He cannot reach the goals he once has fixed by himself. He commits suicide. His suicide is a manifestation of failure, a failure of the society, of the state and of the individual. To live the life is essence of existence, and Loman is forced to breach the bond under some artificial circumstances. Thus, Willy Loman is forced to be brutalized under some brutal forces like Howard or Ben who are also brutalized to live a life like an animal though in the state of a manipulator and oppressor. Linda Loman indicates the failure of Willy Act 1:

I don't say he's a great man. Willy Loman never made a lot of money. His name was never in the paper. He's not the finest character that ever lived. But he's a human being, and a terrible thing is happening to him. So attention must be paid. He's not to be allowed to fall into his grave like an old dog. Attention, attention must be paid to such a person. (Miller, 22)

Willy lived everyday of his life trying to become successful, well-off salesman. His self-image that he portrayed to others was a lie and he was even able to deceive himself with it. He traveled around the country selling his merchandise and maybe when he was younger, he was able to sell a lot and everyone like him, but Willy was still stuck with this image in his head and it was the image he let everyone else know about. In truth, Willy was a senile salesman who was no longer able to work doing what he's done for a lifetime. When he reaches the point where he can no longer handle working, he doesn't realize it, he puts his life in danger as well as others just because he's pig-headed and doesn't understand that he has to give up on his dream. He complains about a lot of things that occur in everyday life, and usually he's the cause of the problems. When he has to pay for the repair bills on the fridge, he bitches a lot and bad mouths Charley for buying the one he should have bought. The car having to be repaired is only because he crashes it because he doesn't pay attention and/or is trying to commit suicide. Willy should have settled with what he had and made the best of things. He shouldn't have tied to compete with everyone and just made the best decision for him using intelligence and practicality. Many of Willy's problems were self-inflicted, the reason they were self-inflicted was because he wanted to live the American dream. If he had changed his standards or just have been content with his life, his life problems would have been limited in amount and proportion. 
Willy's problems in life were usually caused of his chase towards the American dream. Every problem he had and every upsetting or hostile moment he experienced was also inflicted upon Linda, his wife. The hell she went through everyday was because she was his wife. Linda took each day one at a time and each day was filled with stressful worrying about Willy. Imagine how she felt when she found out about Willy's suicidal tendencies, she must have tried extremely hard, as not to take it personally. Linda tried as best she could to try and help Willy, but it wasn't her fault she was not able to get through to him. Willy did not respect Linda or give her the treatment and recognition she deserved. She spent the days mending her silk stockings getting gray hair and worrying about her husband's welfare. Meanwhile Willy found companionship with numerous mistresses and gave away Linda's well-deserved stockings. Linda agrees with everything Willy says and stays content throughout the whole play. The one time she explodes is when the boys came home from the restaurant after leaving Willy alone.

Biff and Happy's futures when they were small all depended on the way they were brought up. Willy was the only one with any say in the way the kids were brought up. Linda went along with whatever Willy said. Willy taught them that if they were handsome and successful, opportunity will come to you. Happy learned nothing from Willy's demise but insists that his father had "the only dream you can have- to come out number-one man". Biff and Happy idolized their father when they were young. The stories they were told made them picture their father as a popular, successful, well-known salesman. As Biff grew up, he found himself being told things about his father like "A salesman has to dream, it comes with the territory." At the end of the story when Linda says they we free, Biff is free to realize his dream of owning a ranch out West where he can live close to the natural world. Biff also realizes that his father had the wrong dreams and didn't know who he was. Biff is sure he won't make the same mistakes his father did. Meanwhile, Happy is more like his dad, determined to stay in town and prove himself to everyone. Having Biff acknowledge the dishonesty of his own life, insists on the end of dream.

Although the Loman's lives were full of many problems, the problems were not all caused by Willy striving for the American dream. Willy's problems, (that usually affected the whole family) were caused by little decisions made throughout his lives. He had a choice of whether or not to do something, he just made the wrong decision most of the time because he wanted to live the American dream. The majority of problems Willy encountered were decide upon with the idea of the American dream in mind, although the end result of the problems were not purposely meant to turn out as bad as they usually did. Willy Loman put his family through endless torture because of his search for a successful life. He should have settled with what he had and been happy. One dream is not worth all the pain and problems his caused, he should have learned to be content and, as harsh as it may be to believe, he should have realized what he could have accomplished and given up on his dream.

Willy cannot see who he and his sons are. He believes that they are great men who have what it takes to be successful and beat the business world. Unfortunately, he is mistaken. In reality, Willy and sons are not, and cannot, be successful. Certain lines in the play point to this character flaw that is present in Willy, Hap, and (for a time) Biff. For example, Willy believes that to be well liked is the means to being successful. This is an illusion that Willy lives in. Also, on the literal level, Willy very often lapses into a flashback and appears to be reliving conversations and situations that occurred years ago. This itself is an inability to see reality. This reality versus illusion problem eventually brings about Willy's downfall. In the end, Willy believes that a man can be "worth more dead than alive." Charlie, always the voice of reality tells Willy, "A man isn't worth anything dead." Willy is also unable to see change. He is man lost in the modern era of technology. He says, "How can they whip cheese?" and is constantly "In a race with the junkyard." Willy has lost at trying to live the American Dream and the play can be viewed as commentary about society. Willy was a man who was worked all his life by the machinery of Democracy and Free Enterprise and was then spit mercilessly out, spent like a "piece of fruit." As Happy says in Requiem:

I'm gonna show you and everybody else that Willy Loman did not die in vain. He had a good dream. It's the only dream you can have-to come out number-one man. He fought it out here, and this is where l'm gonna win for him.

Here, we can surely trace the essence of illusion lying on Happy's mind. We can compare this illusion to Lacan. Real, Symbolic and Imaginary - Lacan believes due to the intoxication of symbolic, the mundane reality is taken under the point of conflict. Proletariat and Bourgeoisie-two different sets distorted by the taboos of society-get around into an indecisive battle of supremacy being unable to discover the "Real". It is the unfortunate fate of mankind that we can never know our own inside through the language-a symbolic apparatus. In Death of a Salesman, Miller reveals how a character is entrapped within a set of tabooed rules-Loman. As a protagonist, Loman can never win the status of a bourgeoisie due to the inward distortion of his psyche. He is out and out a proletariat, a representative of oppressed class, and he can hardly win the battle because the process of brutalization is not only outside but also inside. Loman can become an oppressor like Howard, but he cannot ignore the process forced upon.

Thus, we can have the reasons and the consequences of brutalization of a society that practically try to get its subjects brutalized through its different means. Death of a Salesman is a paragon example of man who fails to make his dreams true until his death comes, and who is forced to be brutal by choosing the way of death as the real solution of everything, of every problem, of his family's future, of his existence in earth.

\section{References}

Althusser, Louis. "Ideology and Ideological State Apparatuses". Literary Theory: An Anthology. Ed. Julie Rivkin and Michael Ryan. USA: Blackwell publishers Inc. 1998. 294-304.

Barry, Peter. Beginning Theory . UK: Manchester University Press, 2002. 
Camus, Albert. The Outsider. UK: Penguin Books, 1982.

Foucault, Michel. "The Archaeology of Knowledge". Literary Theory: An Anthology. Ed. Julie Rivkin and Michael Ryan. USA: Blackwell Publishers Inc. 1998. 421-428.

Hawthorne, Nathaniel. The Scarlet Letter. UK: Penguin Books, 1986.

Ibsen, Henrik. A Doll's House. Trs. William Archer. Dhaka: Friends Book Corner, 2002.

Leela, Gandhi. Postcolonial Theory. New Delhi: Oxford University Press, 1998.

Leguois, Émile. A Short History of English Literature. Hong Kong: Oxford University Press, 1989.

Miller, Arthur. Death of a Salesman. Dhaka: Aligard Library, 1996.

Northam, John. "Ibsen's Search for the Hero". Ibsen. Ed. Rolf Fjelde. USA: Prentice-Hall Inc. \& Englewood Cliffs, N.J. , 1965, 91-108.

Oliver, Paul. World Faiths. UK: Teach Yourself, 2001. 30-36.

Olsen, Tillie. "Silences". Feminist Literary Theory A Reader. Ed. Mary Eagleton. USA: Blackwell Publishers, $1993,53-57$.

Sartre, Jeaun-Paul. Existentialism and Humanism. UK: Eyre Methuen Ltd., 1975.

Smith, Steve. "Louis Althusser (1918-90)". Contemporary Critical Theorist: From Lacan to Said. Ed. Jon Simons. New Delhi: Atlantic Publishers and Distributors, 1998. 51-67.

William. Raymond. Drama from Ibsen to Eliot. UK: Penguin Books, 1964.

Wright, Elizabeth. Lacan and Postfeminism. UK: Icon Books, 2001.

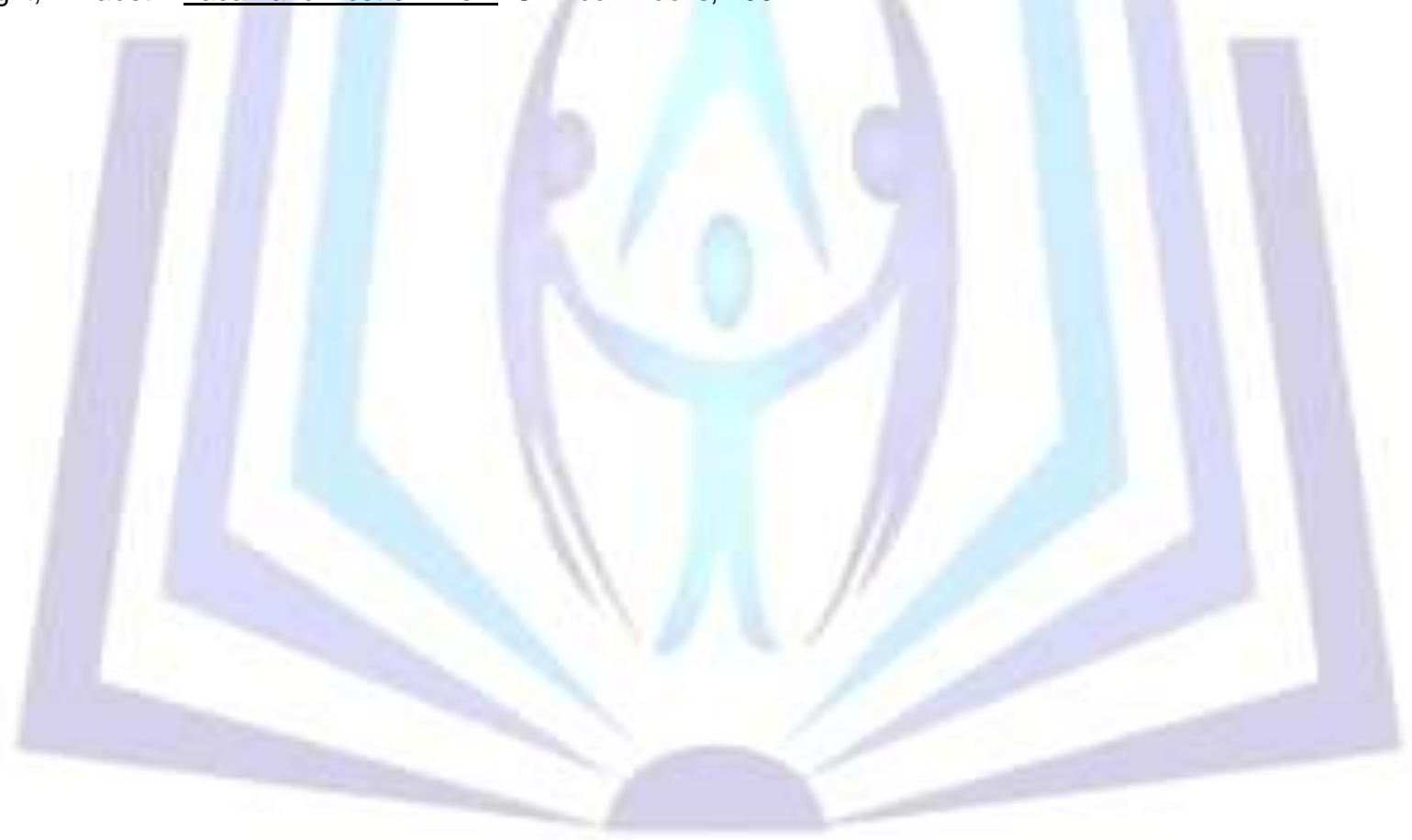

